\title{
Cervical Cancer pT1b TNM Finding v7
}

National Cancer Institute

\section{Source}

National Cancer Institute. Cervical Cancer pT 1b TNM Finding v7. NCI Thesaurus. Code C89530.

Cervical cancer with microscopic lesion greater than T1a/IA2. (from AJCC 7th Ed.) 